\title{
Incentives for accounting choices in Cash Flows Statements ${ }^{\star}$
}

Flávia Fonte de Souza Maciel1

(D) https://orcid.org/0000-0002-3476-4792

Email: flaviamaciel@outlook.com.br

\author{
Bruno Meirelles Salotti² \\ (D) https://orcid.org/0000-0002-2735-7048 \\ Email: brunofea@usp.br
}

\author{
Joshua Onome Imoniana ${ }^{2}$ \\ (D) https://orcid.org/0000-0002-6535-6863 \\ Email: josh.imoniana@usp.br
}

\author{
1 PricewaterhouseCoopers Auditores Independentes, Departamento de Risco e Qualidade, São Paulo, SP, Brazil \\ ${ }^{2}$ Universidade de São Paulo, Faculdade de Economia, Administração e Contabilidade, Departamento de Contabilidade e Atuária, São Paulo, SP, \\ Brazil
}

Received on 08.02.2018 - Desk acceptance on 08.30.2018 - $7^{\text {th }}$ version approved on 08.16.2019 - Ahead of print on 12.09.2019

Ad Hoc Associate Editor: Fernando Caio Galdi

\begin{abstract}
This study sought to identify incentives that influence the accounting choices for classifying interest and dividends received or paid in Cash Flow Statements (CFSs), in the period from 2008 to 2014, in non-financial companies of the Brazilian capital market. The hypotheses refer to the effect of the choice of classification for interest and dividends over cash flow from operations (CFO), according to indebtedness, profitability, size, negative CFO, sector, and auditor. This article seeks to contribute by providing evidence on the accounting choices for classification in CFSs, considering the lack of consensus in the results of studies in the Brazilian capital market and helping to better understand these accounting choices and the incentives behind them. A correct understanding of the information in CFSs is fundamental for them to be useful to their users. The existence of accounting choices for classification in CFSs may directly affect this understanding and, consequently, their usefulness. The results help in better understanding the discretion contained in CFSs, enabling the correct use of their information. They can also generate evidence for regulatory bodies to rethink their accounting rules and for academia to direct future research. Two panel data models were developed, using a sample of 352 companies, 2,290 analyzed reports, and 3,764 data items. The results indicate that companies with a greater level of debt, profitability, and size make their accounting choices in order to report higher CFO in the CFS. The evidence obtained reinforces the international findings and adds new analyses in the Brazilian context, contributing to the development of accounting choice theory.
\end{abstract}

Keywords: Cash Flow Statement, cash flow from operations, accounting choices, classification options.

Correspondence adress

Bruno Meirelles Salotti

Universidade de São Paulo, Faculdade de Economia, Administração e Contabilidade, Departamento de Contabilidade e Atuária

Avenida Professor Luciano Gualberto, 908 - CEP 05508-010

Cidade Universitária - São Paulo - SP - Brazil

*Article presented at the XVI International Congress on Accounting and Auditing, Aveiro, Portugal, October 2017. 


\section{INTRODUCTION}

Choosing means opting, selecting, prefering, electing. It is therefore assumed that there are options to be chosen. In all branches of knowledge, choices are usually made based on criteria and, in the accounting field, this is logically no different.

According to Fields, Lys, and Vincent (2001, p. 256), "accounting choice" is any decision whose main purpose is to influence, in form or in substance, the output of the accounting system in a particular way. This definition is very broad and shows that accounting choices can be studied from different perspectives.

In this paper in particular, the object to be studied and that enables accounting choices is the Cash Flow Statement (CFS). Since the enactment of Law n. 11,638/2007, which established the official start of the process of convergence of the Brazilian accounting rules toward the international rules (International Financial Reporting Standards - IFRS), the disclosure of this statement has become obligatory in Brazil for financial years ending from 2008 onward, the year in which the Accounting Pronouncements Committee (Comitê de Pronunciamentos Contábeis - CPC) issued Technical Pronouncement CPC 03 (Cash Flow Statement) to establish the rules for elaboration and disclosure of CFSs.

The "accounting choices" allowed both by the CPC and by the IFRS are related to the Options for Classification in Cash Flow Statements (OCCFS). Specifically, these choices allow interest and dividends received to be classified as cash flow from operating activities (CFO) or cash flow from investing activities (CFI), while interest and dividends paid can be classified as $\mathrm{CFO}$ or cash flow from financing activities (CFF).

There is also an additional guidance for the Brazilian standard (paragraph 34A of CPC 03) that strongly encourages (i) the classification of interest, whether received or paid, and of dividends received as $\mathrm{CFO}$ and (ii) dividends paid as CFF. Paragraph $34 \mathrm{~A}$ is aligned with the standard Statement of Cash Flows 95 (SFAS 95), originating from the United States Generally Accepted Accounting Principles (USGAAP). The Brazilian standard also highlights that, if the guidance is not followed, this must be disclosed in a footnote.

Due to the flexibility for classifying these flows (interest and dividends, received or paid) given by the standards, preparers can choose where they will present the items mentioned and, in the Brazilian context, must also disclose proper justifications for that choice, if they do not follow the classification "strongly" encouraged by CPC 03 . Thus, if on one hand this flexibility allows for more faithful information to be reported, since the presentation of the CFS can be adapted to the specific circumstances of each company, on the other hand, this same flexibility opens up room for behaviors that may be driven by the incentives of individuals or groups of individuals preparing the accounting statements, by enabling the choice of option that can generate the most convenient information for the company. It can therefore be assumed that there are incentives that guide the accounting choices for classifying in CFSs the items that are susceptible to this flexibility. This assumption is aligned with the ideas of Watts and Zimmerman (1990), who state that accounting is an activity carried out by people and, for that reason, no theory can be generated that predicts and explains accounting phenomena ignoring individuals' incentives.

There is no consensus yet based on the empirical evidence already obtained on this topic, but there is an indication that companies with a higher level of debt, at least theoretically, must have incentives to present higher amounts of CFO. Lee (2012), analyzing American companies, Baik, Cho, Choi, and Lee (2016), observing Korean companies, Gordon, Henry, Jorgensen, and Linthicum (2017), with a sample of companies from 13 countries in Europe, and Souza, Pinto, Nunes, and Lemes (2019), based on data from the Brazilian market, identified this relationship. Other reasons indicated for such choices include size, profitability, and growth opportunities. However, as already highlighted, the evidence obtained is not consistent, which denotes room for continuining this type of investigation. Based on this, the central research question of this article relates to the incentives that define the accounting choices for classification of interest and dividends paid or received in the CFSs of companies of the Brazilian capital market.

The research question considers the specific characteristics of indebtedness, profitability, size, and whether the company has negative $\mathrm{CFO}$ from following the encouragement of CPC 03 (encouraged CFO), as well as general characteristics of the sector to which it belongs and the company's auditor, for the purposes of providing indicators of the incentives for these accounting choices. So, the general aim of this study is to identify the accounting choices for classifying receipts and payments of interest and dividends in CFSs and possible drivers of these choices. To achieve this objective, the correlation between the effect of the option adopted in the CFO 
and the characteristics of the companies (indebtedness, profitability, encouraged CFO, size, sector, and auditor) was analyzed.

\subsection{Justifications and Contributions}

Given the possibility of preparers classifying items in the CFS according to CPC 03 and International Accounting Standard 7 (IAS 7), and considering that CFO is the basis for valuation calculations (Damodaran, 2006), which include forecasts of future cash flows for contracting (Dichev \& Skinner, 2002) and for financial analyses (Estridge \& Lougee, 2007), there may be various reasons for the preparer to choose a particular classification in order to obtain advantages.

This study evaluates whether there are incentives for disclosed CFO to be affected, and, in turn, whether this information, if not adequately presented, can impair the understanding of users regarding the composition of cash flows and in determining the company's value. In spite of this, less attention has been paid to variations in classification in CFSs (Gordon et al., 2017).

In addition, this paper has the potential to provide evidence regarding the discretionary power of managers in terms of how they report cash flow measures, when they opt for one of the classification alternatives in the CFS, which in truth is something that is hardly studied, since the income statement is usually the reference measure in studies involving earnings management. According to Scott (2014, p. 449), accounting profit is formed of CFO, adding or subtracting net accruals, which have levels of discretion and, for that reason, are the basis of the models for measuring the level of earnings management. As CFO calculated in accordance with the CPC or IFRS is also susceptible to discretion, different CFO measures would thus have an impact on the accruals measurement and, consequently, on the level of earnings management calculated, distorting the findings and comparisons with other companies (Maciel, Salotti, \& Imoniana, 2017, p. 198).

In addition, various models for empirical tests involving accounting variables use cash flow measures (for example, value relevance, conservatism, and earnings management) and the different classifications of receipts and payments of interest and dividends can often end up altering the results of these models. Therefore, this paper has the potential to draw attention to the whole strand of academic studies that include these models and use those accounting data based on cash flows.

It warrants mentioning that the object question of this research has been addressed by various recent studies, both at the international level (Baik et al., 2016; Gordon et al., 2017; Lee, 2012) and locally (Silva, Martins, \& Lima, 2018; Souza et al., 2019). These studies, besides demonstrating the relevance of the topic, contain samples and methodologies that diverge from each other (see Table 1 ), as well as not pointing to a consensus in relation to the results obtained, which leads to gaps to be explored. These studies are discussed in section 2 - Theoretical Framework.

Table 1

Differences identified between the studies regarding accounting choices for classification in Cash Flow Statements (CFSs)

\begin{tabular}{|c|c|c|c|}
\hline Criterion & Silva et al. (2018) & Souza et al. (2019) & This study \\
\hline Sample size & 112 & 354 & 352 \\
\hline Sample profile & $\begin{array}{c}\text { New Market (Novo Mercado) } \\
\text { companies }\end{array}$ & $\begin{array}{l}\text { Non-financial publicly-traded } \\
\text { companies }\end{array}$ & $\begin{array}{l}\text { Non-financial publicly-traded } \\
\text { companies }\end{array}$ \\
\hline Period analyzed & 2010 to 2015 (six years) & 2010 to 2015 (six years) & 2008 to 2014 (seven years) \\
\hline Variables tested & $\begin{array}{l}\text { Indebtedness, profitability, } \\
\text { negative CFO, company size, } \\
\text { growth opportunities }\end{array}$ & $\begin{array}{l}\text { Indebtedness, profitability, negative } \\
\text { CFO, company size, growth } \\
\text { opportunities }\end{array}$ & $\begin{array}{l}\text { Indebtedness, profitability, CFO } \\
\text { "encouraged" by CPC 03, company } \\
\text { size, sector, auditor }\end{array}$ \\
\hline Models used & $\begin{array}{l}\text { Difference of mean test and } \\
\text { logistic regression }\end{array}$ & Logistic regression & $\begin{array}{l}\text { Model A: linear regression } \\
\text { Model B: logistic regression }\end{array}$ \\
\hline $\begin{array}{l}\text { Dependent variable } \\
\text { of the regressions }\end{array}$ & $\begin{array}{l}\text { Dummy for classification of } \\
\text { interest paid and dividends } \\
\text { received }\end{array}$ & $\begin{array}{c}\text { Dummy for classification of cash flows } \\
\text { (one regression for each classification } \\
\text { option) }\end{array}$ & $\begin{array}{c}\text { Model A: difference between disclosed } \\
\text { CFO and encouraged CFO } \\
\text { Model B: dummy for classification of } \\
\text { interest paid }\end{array}$ \\
\hline
\end{tabular}

CPC 03 = Accounting Pronouncements Committee Technical Pronouncement (Cash Flow Statement); CFO = cash flow from operations.

Source: Elaborated by the authors. 
In addition, in Brazil, the inclusion of paragraph 34A to CPC 03 configures a particular normative situation that has not yet been studied with the focus given by this paper, even in the studies involving data from the Brazilian market (Silva et al., 2018; Souza et al., 2019), thus warranting and differentiating this study.

\subsection{Delimitations of the Study}

Despite CPC 03 being applicable to entities in general, the study does not cover financial institutions, which, besides having specific accounting rules, usually classify interest, whether paid or received, and dividends received as $\mathrm{CFO}$, due to the nature of their operations. This reality is mentioned in IAS 7 and in CPC 03, which state that there is not a classification consensus for other entities. Insurers were also not included in the sample, due to them having their own rules and also due to the activity, which involves reserving funds to deal with risks and claims. These reserved funds generate financial revenues, linked to the insurers' operation. That is, there is no variability in the classifications of cash flows of financial institutions and insurers, which justifies their exclusion from the sample.

In this paper, all mentions of dividends (received or paid) also cover interest on own capital (IOC). IOC was introduced in Brazil with Law n. 6,404/1976, but it was Law n. 9,249/1995 that made the payment of IOC deductible (within certain limits) for income tax (IT) purposes, which stimulated companies to use these funds as profit distribution. In any case, in economic terms, IOC is the equivalent of dividends, and for that reason has the same accounting treatment (and also the same possibility for classification in the CFS - CFO or CFI if received IOC, or CFO or CFF if paid IOC).

The research focuses on the consolidated CFS, when applicable, of publicly-traded Brazilian companies, since in IFRS the presentation of individual statements is not required. The individual CFS was only used when there were no consolidated statements. Footnotes were not consulted, since the focus of the research is on the criterion for CFS presentation adopted by Brazilian companies. Brazilian companies, of the Brazilian capital market, which are public or publicly-traded, are understood as those whose stocks are traded on the São Paulo Stock Exchange - the Brasil Bolsa Balcão (B3) exchange - and regulated by the Brazilian Securities and Exchange Commission (Comissão de Valores Mobiliários - CVM).

The period analyzed started in 2008, when disclosure of CFSs became compulsory in Brazil, and concluded in 2014, thus covering seven years of data. It is important to highlight that the use of various periods enables the analysis of different financial and performance situations, independently of the factors that would influence such changes, whether crises in the economy or in the sector, or consequences of internal decisions, for example.

\section{THEORETICAL FRAMEWORK}

CFSs, when used in combination with the other accounting statements, provide information that enables users to evaluate the changes in a company's assets and financial structure. The objective of CFSs is to provide information regarding the alterations in an entity's cash flow and cash equivalents accounts, in a particular period, classifying these cash flows as cash flow from operating (CFO), investing (CFI), or financing activities (CFF).

As highlighted in the introduction of this article, the information on cash flows generated by the CFS, according to IFRS and the CPCs, is prepared based on accounting choices regarding the classifications of interest and dividends received or paid. Interest and dividends received can be classified as CFO or CFI and interest and dividends paid can be classified as CFO or CFF. Thus, accounting choice theory (if one exists) is applicable to this context.

\subsection{Accounting Choices}

Fields et al. (2001, p. 256) define accounting choice as any decision whose primary purpose is to influence, in form or in substance, the output of the accounting system in a particular way, including not only published financial statements, but also tax declarations and regulatory records. Cabello and Pereira (2015) state that accounting choice theory studies the how and why behind choices, since regulatory bodies enable various accounting practices for treating the same economic event.

Francis (2001) presents the definition of accounting choice according to Fields et al. (2001) and broadens this definition by relating it with the nature of that choice, which includes, among other forms mentioned by the authors: equally accepted rules [e.g. first in, first out (FIFO) vs. last in, first out (LIFO)]; judgements and estimates (e.g. estimate of useful life of assets); disclosure decisions (e.g. 
level of details in the description of accounting policies); and classification decisions. The latter is the focus of this paper, related to accounting choices for classifying receipts and payments of interest and dividends in the CFS.

The research on accounting choices aims to identify the factors that influence them, considering their possible motivations and consequences. According to Holthausen and Leftwich (1983), accounting choices have economic consequences if the changes in the rules used to calculate the accounting numbers alter the distribution of companies' cash flows or alter the wealth of the parties that use these numbers as a basis for defining contracts and for decision making.

Considering the classification decisions that an accounting choice can involve, there will not necessarily be any alteration in the cash flows effectively distributed and in the wealth of the parties involved, due to the changes in the accounting numbers disclosed. Taking as a reference the theme of this research, the accounting choices in CFSs, the object of this study, do not impact the release of cash flows, but do interfere in the information on the types of cash flows (CFO, CFI, CFF) generated or used by the company in the period presented. Thus, it is not possible to measure the economic consequences of these choices, since they can influence other types of decisions, including in subsequent periods.

Accounting choice theory has been discussed for decades [see Watts and Zimmerman (1986, 1990), Holthausen (1990), and Watts (1992)] and various empirical studies have tested determining factors of such choices [see, for example, Holthausen and Leftwich (1983), Holthausen (1990), Missonier-Piera (2004), Quagli and Avallone (2010), Martínez, Martínez, and Diazaraque (2011), Lorencini and Costa (2012), and Murcia, Souza, and Wuergues (2013)].

According to Watts (1992, p. 242), accounting choice theory is part of a wider theory, the theory of the firm. This author presents the implications of this economic theory for accounting choice and clarifies that the existence of firms creates a demand for accounting (Watts, 1992, p. 248). He also reinforces the idea that the accounting system performs a role in the contractual agreements that accompany the transactions between a company and the parties outside the company. Contracts oblige each agent (managers, owners, creditors, employees, clients, suppliers, auditors, and government) to contribute with resources to the organization (Sunder, 1997, p. 15).

For Sunder (1997, p. 14), in the understanding of accounting, the firm can be seen as a set of contracts, whether explicit or implicit, between rational agents, who according to the constraints on their opportunities and information, do not consciously choose less desirable courses of action over more desirable ones. This reinforces the complexity that can be involved in accounting choices, considering the discretion that managers have when deciding the set of accounting procedures that will be used.

In the following section, the main previous studies related to accounting choices and cash flow measures are described.

\subsection{Previous Studies on Choices for Classification in CFSs}

Lee (2012) studied incentives to inflate CFO in CFSs using classification and timing in companies from the United States of America in the period from 1988 to 2008. This study observed what it called CFO management (CFOM), which is different from earnings management, as indicated by the author. CFOM does not affect the result for the period, that is, this remains constant, as well as the aggregate cash flow, which is the sum of the cash flows from operating, investing, and financing activities. One of the characteristics identified by Lee (2012) to inflate CFO in the CFS was the bankruptcy probability of companies, which indicates there being incentives for the classifications in the CFS.

Baik et al. (2016) examined the changes in CFS classifications in companies that adopted IFRS in Korea, specifically the determining factors and economic consequences of a change in classification of interest paid. It was observed that companies with high indebtedness and a concentrated ownership structure tend to reclassify the amount of interest paid from operating activity to financing activity, thus increasing the value of the $\mathrm{CFO}$ disclosed.

Gordon et al. (2017) studied the flexibility in the choice of CFS classification according to IFRS in companies from 13 European countries, for financial years between 2005 and 2008, and identified determining factors for classification choices that increase CFO related to company characteristics, including profitability and debt. The authors mention the effect of the flexibility of CFS classifications using, as a reference, SFAS 95, which establishes the classification of interest and dividends in a similar way to that encouraged by CPC 03 , in paragraph $34 \mathrm{~A}$.

In Brazil, the debate involving the elaboration and disclosure of CFSs was primarily developed in the 1990s, since the substitution of the Statement of Origins and Applications of Resources (Demonstração das Origens e Aplicações de Recursos - Doar) by the CFS was already being considered at that time, which in fact only occurred as of 2008 , following the alteration in the corporate act that occurred in 2007. Various academic and technical 
papers have been developed based on this discussion and, specifically in relation to accounting choices, two studies by Santos and Lustosa, from 1999 and 2000, warrant attention. In these two papers, published in the journal Temática Contábil e Balanços (Accounting and Balance Sheets), by Informações Objetivas e Publicações Jurídicas $(I O B)$ (Objective Information and Legal Publications), the authors discussed in depth the options for classifying interest and dividends paid (in the first article) and received (in the second) and, at the end, suggested that, technically, interest and dividends paid should be classified in financing activity and interest and dividends received should be classified in investing activity. This suggestion, if embraced, would have eliminated the possibility of accounting choices and, consequently, the possible opportunistic behaviors of the preparers of financial statements. However, this did not occur, since, as already highlighted in the Introduction, Brazil essentially adopted the IASB model, which enables such choices.

Subsequently to this debate and in the face of the definitive adoption of the CFS in Brazil, Silva et al. (2018) investigated the accounting choices in CFS disclosure, in the period from 2010 to 2015, of the companies listed on the New Market (Novo Mercado) of the São Paulo Stock, Commodities, and Futures Exchange (BM\&FBOVESPA), which establishes a higher standard of corporate governance, with a total sample of 112 companies. In line with the present research, they considered the classification of interest and dividends, paid and received, with the aim of identifying factors that explained these choices. They analyzed aspects related to debt, profitability, negative $\mathrm{CFO}$, company size, and growth opportunities as incentives for choices that increase CFO. The results of the research by Silva et al. (2018) did not present conclusive evidence that the accounting choices in the CFSs were related to debt, profitability, or negative CFO. In contrast, they partially accepted the company size and growth opportunities hypotheses. The authors indicate that the results obtained are not consistent with previous studies, probably due to implications of other variables not analyzed by them. In addition, it should be highlighted that the sample studied by Silva et al. (2018) is restricted to companies of the New Market, thus limiting the findings.

Another study with data from the Brazilian market was developed by Souza et al. (2019). The aim of that research was to identify the level of comparability of the accounting choices related to the CFS and factors that could explain such choices. A sample of 354 non-financial publiclytraded companies was chosen, covering the period from 2010 to 2015 , and the choices relating to interest and dividends received and paid were analyzed, along with IT paid. The variables tested considered the company's size, level of debt, profitability, growth opportunities, and negative CFO. All the hypotheses were confirmed, to a greater or lesser extent, suggesting that the companies of the Brazilian market use accounting choices to manage cash flows.

Therefore, the empirical evidence related to the accounting choices for classifying cash flows in the CFS are still not conclusive, which suggests more empirical investigation. In any case, they appear to indicate the existence of incentives for the classification of cash flows in the CFS, especially with relation to the indebtedness variable, which showed greater empirical consistency in the findings. In the next section, the hypotheses of this study are constructed and underpinned.

\subsection{Development of the Hypotheses}

The research question guiding this study covers incentives that define the accounting choices for classifying interest and dividends paid or received in the CFSs of companies of the Brazilian capital market. Thus, in order to answer this question, four hypotheses are developed, described, and underpinned below.

\subsubsection{Indebtedness}

If a company has a high level of debt, this may indicate a situation of financial difficulty. Thus, there is naturally an incentive for that company to want to report a higher $\mathrm{CFO}$, since this could indicate to current and potential interested parties (creditors and investors) that the entity would be able to meet its financial commitments and would not enter into a bankruptcy situation.

The studies described in section 2.2 tested this reasoning. Lee (2012) documented the existence of a relationship between the CFS classifications and the bankruptcy probability. Baik et al. (2016) observed a positive relationship between Korean firms with higher indebtedness and changes in the classification of interest paid from CFO to FCF. Gordon et al. (2017) reached the same conclusion on this, also mentioning that companies that have contracts and costs involved in renegotiations seek to report a higher CFO. Silva et al. (2018) and Souza et al. (2019) also tested the relationship between the level of debt and choices in the CFS, and only Souza et al. (2019) identified a correlation.

Thus, the following hypothesis was developed:

$\mathrm{H}_{1}$ : companies with a high level of debt tend to choose the classification that increases CFO. 


\subsubsection{Profitability}

Based on the previous hypothesis, assuming that "bad news" would incentivize an accounting choice to improve the CFO, then it can be expected that a company with higher profitability would be less likely to manage an increase in CFO, since it has a positive situation in its favor. However, despite agreeing with this idea, Gordon et al. (2017) also counter it, by assuming that a more lucrative company could be motivated to present a higher $\mathrm{CFO}$ to show consistency between income generation and cash flow. Silva et al. (2018) also support this argument, although they recognize that companies with negative CFO have incentives for classifications that make it less negative or even positive.

For the purposes of this work, the first line of reasoning is sustained, in order to maintain consistency with $\mathrm{H}_{1}$ and with the argument that companies tend to present more favorable information as an attempt to compensate for some unsatisfactory situation, which in this case would be lower profitability.

Thus, the following hypothesis is elaborated:

$\mathrm{H}_{2}$ : companies with lower profitability tend to choose the classification that increases CFO.

\subsubsection{Effects of the "encouragement" of CPC 03}

As described in the introduction of this article, CPC 03 introduced paragraph $34 \mathrm{~A}$ (non-existent in the respective standard IAS 7), which strongly encourages entities to classify interest and dividends received and interest paid as $\mathrm{CFO}$ and dividends paid as CFF. Based on this, it was considered that companies that would report negative $\mathrm{CFO}$, following the encouragement of $\mathrm{CPC} 03$, have incentives to attenuate this situation or even invert it. For that reason, it is expected that if the encouraged $\mathrm{CFO}$ is negative, the greater the chance is of managing an increase in the $\mathrm{CFO}$ disclosed. Despite the previous studies analyzed not using this characteristic, it was developed by analogy to the cases involving incentives to report positive results instead of negative ones, according to the research of Burgstahler and Dichev (1997). Thus, the third hypothesis was developed:
$\mathrm{H}_{3}$ : companies with negative $\mathrm{CFO}$ in accordance with the encouragement of CPC 03 tend to choose the classification that increases CFO.

\subsubsection{Size}

The size of companies is a characteristic that can affect the classification choices in the CFS, since the bigger the company, the more incentives there are to present a higher CFO. This incentive may be linked to the political visibility of the company; that is, as they have more visibility, bigger firms may feel pressured to choose cash flow classifications that increase CFO. Watts (1992) suggests that the political process affects accounting choices.

Silva et al. (2018) and Souza et al. (2019) tested this variable in their studies and found indications that the company's size has an impact on the accounting choices for classification in CFSs.

Lee (2012), Baik et al. (2016), and Gordon et al. (2017) also include this variable in the models, however as a control variable. In spite of this, it is understood that the political visibility argument is consistent and warrants the inclusion of size as an explanatory variable.

Thus, the fourth hypothesis was raised:

$\mathrm{H}_{4}$ : bigger companies tend to choose the classification that increases CFO.

\subsubsection{Control variables: sector and auditor}

There are no hypotheses regarding the variables related to the sector and auditor of the companies, since there is no specific expected effect on CFO due to these general characteristics. However, considering that companies' characteristics can be influenced by the sector in which they operate and the auditing firm that audits them, these variables were considered in the model as control variables; that is, by including these variables in the model, it is possible to evaluate the incremental effect of the other variables.

Having developed and underpinned the hypotheses, the next section describes the methodological procedures.

\section{METHODOLOGY}

The analysis of the gathered data and their relationships enables it to be evaluated whether there are incentives for the CFO to be affected through the choice of classification of interest and dividends. The motives for adopting a particular accounting practice and changing them is the object of positive accounting research.

The values of total assets, CFO, return on assets, and indebtedness, as well as the Corporate Taxpayers' 
Registration (Cadastro Nacional da Pessoa Jurídica CNPJ) of the companies chosen, were obtained from the Economatica ${ }^{\circledR}$ database. These financial and accounting data considered consolidated values from the 12-month period ending on December $31^{\text {st }}$. The CFSs were extracted from the Full Annual Financial Statements (annual FSs), held on the website of the CVM (the regulatory body for the Brazilian capital market), after searching by CNPJ.

Only cases with an explicit indication in the CFS of interest and dividends, whether paid or received, were included in the database, independently of the motive for not presenting this information, whether it was not applicable or because it did not feature. Another criterion adopted concerns the cases in which in the financial year there were no values for the items under analysis, but there was CFS information because there was an amount from the previous comparative period, so the classification of the financial year in question was tabulated and indicated with a 0 value.

The list of companies for analysis of the respective data was taken from the Economatica ${ }^{\circledR}$ database. The filters of Brazil as the host country, company with an active status, and the most traded stock were used in order to avoid repetition of companies. The industry segments filter was also used and the companies classified as "Finance and Insurance" and "Funds" were excluded from the database, since financial institutions do not form part of the scope of the research. Therefore, 352 companies were initially selected.

Next, the annual FSs from 2008 to 2014 of these companies were obtained. Companies with an accounting year ending in other periods that were not December $31^{\text {st }}$ were excluded, given that the financial and accounting data collected were from this base date.

Data with inconsistencies (e.g. positive interest paid, negative dividends received, etc.) were also excluded from the sample, as well as cases in which the CFS was not presented, was not legible (low quality of scanned copy), or missing some part (second page of the CFS). Appendix A details the periods and companies with such occurrences.

Table 2 presents the reconciliation of the difference between the predicted quantity of annual FSs that would be analyzed, if the 352 companies chosen had disclosure in all the financial years, and the final quantity actually used in the research. This difference is the result of annual FSs that were not disclosed, due to the company only having disclosed financial statements in some of the years.

Table 2

Reconciliation of the quantity of Annual Financial Statements (FSS)

\begin{tabular}{|c|c|c|c|c|c|c|c|c|}
\hline Year & 2008 & 2009 & 2010 & 2011 & 2012 & 2013 & 2014 & Total \\
\hline Predicted annual FSs of the chosen companies & 352 & 352 & 352 & 352 & 352 & 352 & 352 & 2,464 \\
\hline \multicolumn{9}{|l|}{ Exclusions } \\
\hline Other accounting years & -2 & -3 & -4 & -4 & -5 & -4 & -4 & -26 \\
\hline Inconsistencies in the data & -1 & -2 & & -2 & -3 & -3 & -1 & -12 \\
\hline CFS not presented, illegible, or incomplete & & -1 & & -3 & -1 & -2 & & -7 \\
\hline Annual FSs not disclosed & -41 & -32 & -21 & -14 & -3 & -1 & -17 & -129 \\
\hline Annual CFs used in the research & 308 & 314 & 327 & 329 & 340 & 342 & 330 & 2,290 \\
\hline
\end{tabular}

CFS $=$ Cash Flows Statement.

Source: Elaborated by the authors.

Via the analysis of the CFSs featuring in the 2,290 annual FSs, the data were collected relating to the companies' interest and dividends cash flows. Table 3 provides a summary of the quantity of data gathered through that analysis, considering that each annual FS may have from zero to four collected data items, depending on the items (interest paid, interest received, dividends paid, and dividends received) that feature in the respective CFS.

Table 3

Summary of the data collected (by year)

\begin{tabular}{lcccccccc}
\hline Year & $\mathbf{2 0 0 8}$ & $\mathbf{2 0 0 9}$ & $\mathbf{2 0 1 0}$ & $\mathbf{2 0 1 1}$ & $\mathbf{2 0 1 2}$ & $\mathbf{2 0 1 3}$ & $\mathbf{2 0 1 4}$ & Total \\
\hline Interest paid & 94 & 117 & 162 & 177 & 194 & 200 & 201 & 1,145 \\
\hline Interest received & 9 & 13 & 15 & 16 & 16 & 15 & 13 & 97 \\
\hline Dividends paid & 189 & 198 & 217 & 220 & 228 & 233 & 232 & 1,517 \\
\hline Dividends received & 111 & 124 & 134 & 147 & 158 & 169 & 162 & 1,005 \\
\hline Total data collected & 403 & 452 & 528 & 560 & 596 & 617 & 608 & 3,764 \\
\hline
\end{tabular}

Source: Elaborated by the authors. 
The data indicated in Table 3 were used to direct the research hypotheses. The exception occurs for the data indicated on the first line of that table, since of the total of 1,145 data items regarding interest paid, four were excluded from the database to run the regression that has interest paid as the dependent variable (model B), resulting in 1,141 used data items. The excluded data refer to the company Dommo Empreendimentos Imobiliários S.A., whose profitability and debt indices distort the descriptive analyses as they are too high. In 2011, for example, this company had a net loss of $\mathrm{R} \$ 6,043,625.00$, total assets of $\mathrm{R} \$ 61,119.00$, and total liabilities of $\mathrm{R} \$ 9,048,644.00$, resulting in profitability and debt indices of $4,168 \%$ and $6,240 \%$, respectively, when the mean for the period was from $4 \%$ to $61 \%$ (excluding that company). Except for the exclusion of the data from that company, no other treatment was needed for outliers.

With the aim of reaching a conclusion regarding the rejection or not of the hypotheses, two dependent variables were considered for the analysis of the effect on $\mathrm{CFO}$ derived from the choice of classification: (i) the difference in reais between the disclosed CFO and the value that the $\mathrm{CFO}$ would be from following the options encouraged by CPC 03 (encouraged CFO) and (ii) the choice of classification for interest paid. The first variable was divided by the value of total assets, in order to exclude the effect of any possible variability due to the company's size. The analysis of the second dependent variable, using logistic regression, was directed at interest paid, since if it is classified in the CFS as CFF (without following the classification recommended by the CPC), this will result in an improvement in cash flows from operating activities; the opposite occurs if it is classified as CFO. This improvement, from not following the recommendation of the CPC, does not occur with the other alternatives (interest received, dividends received and paid). This targetting was elaborated based on the research of Gordon et al. (2017).

Finally, the relationship between the dependent and explanatory variables was analyzed using panel data. This relationship is presented in Table 4, which also indicates the proxies used and the expected effect on $\mathrm{CFO}$ of each one.

\section{Table 4}

Models and variables of the hypotheses

\begin{tabular}{|c|c|c|c|c|}
\hline Model & Dependent variable & Explanatory variables & Proxies & Expected effect on CFO \\
\hline \multirow{2}{*}{ A } & \multirow{2}{*}{$\begin{array}{l}\text { Difference in reais between the } \\
\text { disclosed CFO and encouraged CFO } \\
\text { divided by the value of total assets }\end{array}$} & Indebtedness* & $\begin{array}{l}\text { General indebtedness (total } \\
\text { liabilities/total assets } \times 100 \text { ) }\end{array}$ & + \\
\hline & & Profitability & $\begin{array}{c}\text { Return on assets (net income/total } \\
\text { assets } \times 100 \text { ) }\end{array}$ & - \\
\hline \multirow[t]{2}{*}{ B } & \multirow{2}{*}{$\begin{array}{c}\text { Choice of classification for interest } \\
\text { paid (dummy, } 1 \text { for classification as } \\
\text { CFF and } 0 \text { for CFO) }\end{array}$} & Encouraged CFO & $\begin{array}{c}\text { CFO in accordance with } \\
\text { encouragement of CPC } 03 \text { (dummy, } \\
1 \text { if negative and } 0 \text { if positive) }\end{array}$ & + \\
\hline & & Size & Natural logarithm of total assets & + \\
\hline
\end{tabular}

CPC 03 = Accounting Pronouncements Committee Technical Pronouncement (Cash Flow Statement); CFF = cash flow from financing activities; CFO = cash flow from operating activities.

* = another debt index was considered in the regressions (total loans and financing divided by assets), but it did not generate divergent results; + = positive; - = negative.

Source: Elaborated by the authors.

As commented in the development of the hypotheses (section 2.3), the expected effect on CFO is related to the company's need to present more favorable information in order to compensate for some unsatisfactory situation. For this reason, the more indebted the company is, or the less profitable it is, or if it has a negative encouraged $\mathrm{CFO}$, the more the classification options are expected to be used to increase the amount of CFO presented. Regarding size, the existence of incentives for favorable reports is considered in bigger companies.

When determining the sectors, the sector classification of Economatica ${ }^{\circledR}$ was used, composed of: Agriculture and fishing; Food and drink; Commerce; Construction; Electro domestics; Electrical energy; Industrial machinery; Mining; Non-metal minerals; Pulp and paper; Oil and gas; Chemicals; Steel and metal; Software and data; Telecommunications; Textiles; Transport Services; Vehicles and parts; and Others, totaling 19 sectors. Finally, five groups of independent auditors were considered: four are composed of each one of the Big Four and another group is formed of the other auditing firms. This grouping enables the identification of the similarities and differences of treatment of each one of the Big Four and the other auditors with respect to their agreement regarding the classification in the CFS of interest, dividends, and IOC.

The panel data analysis covers two dimensions: one cross-sectional, represented by the companies, and one 
longitudinal, represented by time. Thus, information from more than one individual was obtained over one time period. The use of panel data also enables the use of a greater number of observations than would be possible if only cross-sectional or only longitudinal data were used (Baltagi, 1998, cited by Gujarati, 2006). In this study, the individuals are represented by 171 companies in model A and 234 companies in model B, observed over seven years, involving an unbalanced panel, since there are companies with data in only some years.
Finally, it warrants mentioning that this study has methodological differences in relation to those of Silva et al. (2018) and Souza et al. (2019). Table 1 summarizes these differences and, from its analysis, it is noted that this study considers a longer period in relation to the previous ones and has as differentials the analysis of the "encouragement" of CPC 03 and the inclusion of the sector and auditor control variables. In addition, the use of two regression models together with these differentials may capture a relationship between the variables that the previous studies did not.

\section{RESULTS}

This section presents the results of the regressions, separating the two regression models used. As previously indicated in Table 4, model A has "difference" as the dependent variable, which represents the difference in reais between the $\mathrm{CFO}$ disclosed and the value that the $\mathrm{CFO}$ would be from following the options encouraged by CPC 03 (encouraged CFO) divided by the value of total assets. Model B has "interest paid" as the dependent variable, which refers to the choice of classification for interest paid - a dummy variable that is 1 for classification as CFF and 0 if CFO. The explanatory variables (debt, profitability, encouraged CFO, and size) and the control variables (sector and auditor) are the same in the two models.

The descriptive analyses of each model, using the mean, frequency, standard deviation, and median, are presented in appendices B and C.

Each regression was tested using the fixed effects model and the random effects model. All the models were estimated considering the inclusion of six dummy variables corresponding to the years studied. Six variables were included (and not seven, from 2008 to 2014), to avoid the problem of multicollinearity, and the Wald test was used to verify the relevance of those variables in the model. The aim of this test is to verify whether the parameters of the dummy variables are together equal to 0 , which would indicate there being no statistical importance to keep them in the model.
The significance from the Wald test resulted in a value greater than 0.05 in all cases, indicating that the parameters of the dummy variables are together equal to 0 and, therefore, should be excluded from the model. That is, these variables were not able to capture macroeconomic factors that could have affected the companies in the period analyzed. This indicates that in no year was there discordant behavior compared to the others, which may be related to relevant external factors from a particular year, such as a serious crisis or specific economic events.

All the models were also estimated considering the classification of the auditors into two groups ("Big Four" vs. others), not resulting in different conclusions from the five groups (each one of the "Big Four" and others) considered.

\subsection{Model A}

To carry out the regression, only the periods of the companies in which there was a difference between the amount of CFO disclosed and the encouraged CFO were considered, resulting in the use of 171 companies and 585 data items.

To evaluate which of the models (fixed effects or random effects) is the most adequate, two tests were used: the Breusch-Pagan Lagrange multiplier (BreuschPagan test) and the Hausman test. Their results can be found in Table 5 .

Table 5

Breusch-Pagan and Hausman tests (model A)

\begin{tabular}{lcc}
\hline & Breusch-Pagan Test & Hausman Test \\
\hline $\mathrm{H}_{0}$ & Variance of the unit-specific error $=0$ & The estimates of the random effects model are consistent. \\
\hline Chi-squared & 48.4693 & 86.4456 \\
\hline p-value & $<0.0001$ & $<0.0001$ \\
\hline Conclusion & The pooled model is rejected & $\begin{array}{c}\text { The random effects model is rejected, so the applicable } \\
\text { model is the fixed effects one. }\end{array}$ \\
\hline
\end{tabular}

Source: Elaborated by the authors. 
As the significance (p-value) of the Breusch-Pagan test was lower than 0.05 , it is concluded that between the pooled model and the random effects model, the random effects one is the most adequate. Using the Hausman test, the most adequate model between fixed effects and random effects is evaluated, concluding that the best one is the fixed effects model, since the p-value of this test was lower than 0.05, that is, it was significant (Gujarati, 2006).

Model A was estimated according to the equation below:

$$
\begin{gathered}
\text { Difference }_{\mathrm{i}, \mathrm{t}}=\beta_{0}+\beta_{1} \text { Debt }_{\mathrm{i}, \mathrm{t}}+\beta_{2} \text { Prof }_{\mathrm{i}, \mathrm{t}}+ \\
\beta_{3} \text { CFO }_{\mathrm{i}, \mathrm{t}}+\beta_{4} \text { Size }_{\mathrm{i}, \mathrm{t}}+\beta_{5} \text { Sect }_{\mathrm{i}}+\beta_{6} \text { Aud }_{\mathrm{i}, \mathrm{t}}+\varepsilon
\end{gathered}
$$

in which Difference $e_{i, t}$ is the difference in reais (of company $i$ in year $t$ ) between the CFO disclosed in the CFS and the "encouraged CFO", which is the CFO value constructed by following the classifications in the CFS encouraged by CPC 03 , divided by the value of total assets on
December 31st of year $t, \beta_{0}$ is the constant, $\beta_{1}, \beta_{2}, \beta_{3}, \beta_{4}$ $\beta_{5}, \beta_{6}$ are the coefficients of the equation, Debt $t_{i, t}$ is the general indebtedness (of company $i$ in year $t$ ), calculated by the division between total liabilities and total assets on December $31^{\text {st }}$ of year $t, \operatorname{Prof}_{\mathrm{i}, \mathrm{t}}$ is the profitability (of company $i$ in year $t$ ), calculated by the division between the net income of year $t$ and the total assets on December $31^{\text {st }}$ of year $t, C F O_{i, t}$ is the encouraged CFO (of company $i$ in year $t$ ), a dummy variable, which is 1 if the CFO is negative and 0 if it is positive, Size $e_{i, t}$ is the size (of company $i$ in year $t$ ), calculated based on the natural logarithm of the total assets on December $31^{\text {st }}$ of year $t, S_{e c t}$ is the sector of company $i$ based on the sector classification of Economatica $^{\circledR}, A u d_{i, t}$ is the auditor (of company $i$ ) related to the financial statements (for year $t$ ), and $\varepsilon$ is the error term of the model.

Table 6 shows the data from the regression and the coefficients obtained, using the fixed effects model, defined based on the Hausman test for model A.

Table 6

\begin{tabular}{|c|c|c|c|c|}
\hline & Coefficients & Standard error & $\mathbf{t}$ & p-value \\
\hline Constant & -0.976873 & 0.102748 & -9.508 & $<0.001^{* * *}$ \\
\hline Debt & 0.000306906 & 0.000152498 & 2.013 & $0.0448^{* *}$ \\
\hline Profitability & $4.82271 \times 10^{-5}$ & $8.68074 \times 10^{-6}$ & 5.556 & $<0.001^{* * *}$ \\
\hline CFO & 0.00831131 & 0.0078285 & 1.062 & 0.2890 \\
\hline Size & 0.0660726 & 0.00705278 & -0.5224 & $<0.001^{* * *}$ \\
\hline Sector & \multicolumn{4}{|c|}{ Variable excluded from the model due to the exact collinearity } \\
\hline Auditor & 0.000346343 & 0.00272688 & 0.1270 & 0.8990 \\
\hline Data & \multicolumn{4}{|c|}{ Quantity/value } \\
\hline Cross section & \multicolumn{4}{|c|}{171 units } \\
\hline Time series & \multicolumn{4}{|c|}{ Minimum of $1 /$ maximum of 7} \\
\hline $\mathrm{F}$ & \multicolumn{4}{|c|}{2.67904} \\
\hline$p$-value & \multicolumn{4}{|c|}{$<0.001$} \\
\hline $\mathrm{R}^{2}$ & \multicolumn{4}{|c|}{0.534079} \\
\hline Standard error & \multicolumn{4}{|c|}{0.0533} \\
\hline
\end{tabular}

Summary of the coefficients of model A (fixed effects)

CFO = cash flow from operating activities.

** $=p$-value $<0.05 ;{ }^{* * *}=p$-value $<0.01$.

Source: Elaborated by the authors.

From Table 6, it can be seen that the debt, profitability, and size variables have a significant coefficient, that is, p-value $<0.05$ (Gujarati, 2006), directly influencing (positive coefficient) the difference in reais between the disclosed CFO and the CFO encouraged by CPC 03; that is, the greater the debt, profitability, and size, the greater the difference. In addition, the random effects model, although it is not the most adequate according to the results of the Breusch-Pagan and Hausman tests presented in Table 5, generates results that confirm the significance of the debt and size variables, obtained via the fixed effects model.

Therefore, based on model $\mathrm{A}$, only $\mathrm{H}_{3}$ was rejected, related to the calculation of a negative $\mathrm{CFO}$ following the encouragement of CPC 03. The results appear to indicate that more indebted companies may be using their accounting choices in the CFS to disclose a more favorable CFO. Gordon et al. (2017) identified debt (positive correlation) and profitability (negative correlation) as significant variables influencing the difference between the disclosed CFO and the value that the CFO would be 
following the U.S. standard SFAS 95, which considers the same classifications encouraged by CPC 03 . Table 6 indicates that more profitable companies tend to present a higher CFO (positive correlation), the opposite behavior from what was expected for this hypothesis and from the behavior identified by Gordon et al. (2017). On the other hand, the results indicate that the bigger the company, the greater the CFO presented, which may be related to internal incentives for favorable reports. The size variable was not significant in the research of Gordon et al. (2017). Regarding the control variables related to the sector and auditor, the results did not indicate any significant relationship, similarly to the study by Gordon et al. (2017).

The studies with data from the Brazilian market, despite using data models that are not directly comparable with this research (as presented in Table 1), obtained some different results. Silva et al. (2018) obtained significance only for the size and growth opportunities variables (the latter was not tested in this article), which was not identified for the debt and profitability variables. Souza et al. (2019) obtained significance in all the variables tested, including the size, debt, and profitability variables with a direct correlation, similarly to this study. Logically, the methodological differences may explain the disparity of the findings.

\subsection{Model B}

To carry out the regression of model B, only the periods of the companies in which there was disclosure of interest paid were considered, resulting in the use of 234 companies and 1,141 data items.

To evaluate which of the models (fixed effects or random effects) is the most adequate, two tests were used: the Breusch-Pagan Lagrange multiplier (BreuschPagan test) and the Hausman test. Their results can be found in Table 7.

Table 7

Breusch-Pagan and Hausman tests (model B)

\begin{tabular}{lcc} 
& Breusch-Pagan Test & Hausman Test \\
\hline $\mathrm{H}_{0}$ & Variance of the unit-specific error $=0$ & The estimates of the random effects model are consistent \\
\hline Chi-squared & $1,463.52$ & 2.57057 \\
\hline p-value & 0 & 0.765832 \\
\hline Conclusion & The pooled model is rejected & The random effects model is accepted \\
\hline
\end{tabular}

Source: Elaborated by the authors.

As the significance (p-value) of the Breusch-Pagan test was lower than 0.05 , it is concluded that between the pooled model and the random effects model, the random effects one is the most adequate. This conclusion is corroborated by the Hausman test, since the p-value of this test was greater than 0.05 ; that is, it was not significant. Therefore, the best one is the random effects model, since $\mathrm{H}_{0}$ was not rejected.

Model B was estimated according to the equation below:

$$
\begin{aligned}
& \text { Interest paid } \\
& \mathrm{i}, \mathrm{t}=\beta_{0}+\beta_{1} \text { Debt }_{\mathrm{i}, \mathrm{t}}+\beta_{2} \operatorname{Prof}_{\mathrm{i}, \mathrm{t}}+ \\
& \beta_{3} \mathrm{CFO}_{\mathrm{i}, \mathrm{t}}+\beta_{4} \operatorname{Size}_{\mathrm{i}, \mathrm{t}}+\beta_{5} \operatorname{Sect}_{\mathrm{i}}+\beta_{6} \operatorname{Aud}_{\mathrm{i}, \mathrm{t}}+\varepsilon
\end{aligned}
$$

in which Interest paid ${ }_{i, t}$ is the choice of classification for interest paid in the CFS of company $i$ in year $t$ (dummy variable, which is 1 if the interest paid was classified as CFF and 0 if CFO), $\beta_{0}$ is the constant, $\beta_{1}$, $\beta_{2}, \beta_{3}, \beta_{4}, \beta_{5}, \beta_{6}$ are the coefficients of the equation, Debt $t_{i, t}$ is the general indebtedness (of company i in year $t$ ), calculated by the division between total liabilities and total assets on December $31^{\text {st }}$ of year $t, \operatorname{Prof}_{\mathrm{i}, \mathrm{t}}$ is the profitability (of company $\mathrm{i}$ in year $\mathrm{t}$ ), calculated by the division between the net income of year $t$ and the total assets on December $31^{\text {st }}$ of year $t, \mathrm{CFO}_{\mathrm{i}, \mathrm{t}}$ is the encouraged $\mathrm{CFO}$ (of company $\mathrm{i}$ in year $\mathrm{t}$ ), a dummy variable, which is 1 if the CFO is negative and 0 if it is positive, Size $_{i, t}$ is the size (of company i in year $t$ ), calculated based on the natural logarithm of total assets on December $31^{\text {st }}$ of year $t, S \mathrm{Ct}_{\mathrm{i}}$ is the sector of company $\mathrm{i}$ based on the sector classification of Economatica ${ }^{\circledR}$, and $\mathrm{Aud}_{\mathrm{i}, \mathrm{t}}$ is the auditor (of company i) related to the financial statements (for year $\mathrm{t}$ ).

Table 8 shows the data from the regression and the coefficients obtained using the random effects model for model B. 
Table 8

Summary and coefficients of model B (random effects)

\begin{tabular}{|c|c|c|c|c|}
\hline & Coefficients & Standard error & $\mathbf{T}$ & p-value \\
\hline Constant & 0.493560 & 0.227227 & 2.172 & $0.0298^{* *}$ \\
\hline Debt & 0.000865479 & 0.000322472 & 2.684 & $0.0073^{* * *}$ \\
\hline Profitability & $4.00130 \times 10^{-6}$ & $3.44762 \times 10^{-5}$ & 0.1161 & 0.9076 \\
\hline CFO & 0.0109755 & 0.0235966 & 0.4651 & 0.6418 \\
\hline Size & -0.0112590 & 0.0135501 & -0.8309 & 0.4060 \\
\hline Sector & 0.00251283 & 0.00502041 & 0.5005 & 0.6167 \\
\hline Auditor & -0.00748195 & 0.00716119 & -1.045 & 0.2961 \\
\hline Data & \multicolumn{4}{|c|}{ Quantity/value } \\
\hline Cross section & \multicolumn{4}{|c|}{234 units } \\
\hline Time series & \multicolumn{4}{|c|}{ Minimum of $1 /$ maximum of 7} \\
\hline "Within" the variance & \multicolumn{4}{|c|}{0.0528398} \\
\hline "Between" the variance & \multicolumn{4}{|c|}{0.191822} \\
\hline Standard error & \multicolumn{4}{|c|}{0.483454} \\
\hline
\end{tabular}

CFO = cash flow from operating activities.

** $=p$-value $<0.05 ; * * *=p$-value $<0.01$.

Source: Elaborated by the authors.

From Table 8 , it can be seen that only the debt variable has a significant coefficient ( $\mathrm{p}$-value $<0.05$ ), indicating there is a direct relationship between indebtedness and the classification of interest paid as CFF, which, in turn, generates an increase in the disclosed CFO. Using the same comparison made in model $\mathrm{A}$, these results were compared with those obtained by the fixed effects model, although that one is not the most adequate, according to the Breusch-Pagan and Hausman tests presented in Table 7. The results confirm the statistical significance of the debt variable.

As in model $\mathrm{A}$, this result is in accordance with the expected effect (Table 4) and consistent with the one presented by Gordon et al. (2017), in which again they identified the debt variable as significant in another model that used the classification of interest paid in the CFSs of a sample of European companies.

Baik et al. (2016) identified that Korean firms with higher debt and a bigger size tend to change the classification of interest paid from CFO to CFF, revealing that these characteristics are incentives for disclosing a better $\mathrm{CFO}$. However, variables related to profitability were not statistically significant. Variables related to sector and the auditor were not used in the aforementioned research.

The tests in the study by Silva et al. (2018), which considered the debt, profitability, negative CFO, size, and growth opportunities variables in its logistic regression model with the choice of classification for interest paid as the dependent variable, presented significance only for the size variable. This divergence may be influenced by the difference in the samples and periods studied. For the regression of interest paid, the research of Souza et al. (2019) presented the same result documented here: significance of the debt variable.

Again, based on model $\mathrm{B}, \mathrm{H}_{1}$ was not rejected. Therefore, from different perspectives (models $\mathrm{A}$ and B) and as also documented by a large portion of the other studies on this topic, the debt variable showed a positive and statistically significant relationship, indicating that this is a possible incentive for the accounting choices for classification of interest and dividends paid or received in the CFSs of companies of the Brazilian capital market.

\section{CONCLUSIONS}

The possibility of choosing one classification in the CFS from various relates to the incentives that determine that accounting choice. In general, the incentives identified in this research in the context of the Brazilian capital market relate to the financial situation (indebtedness and profitability) and to the size of the companies.
The results of the regressions showed that indebtedness influences the difference between the disclosed CFO and the value that the $\mathrm{CFO}$ would be if the options encouraged by CPC 03 were followed, as well as the classification of interest paid as CFF. They identified that the greater the indebtedness, the greater the difference, that is, the 
greater the value of the disclosed $\mathrm{CFO}$ in relation to the $\mathrm{CFO}$ encouraged by $\mathrm{CPC} 03$, and that there is a direct relationship (positive coefficient) between indebtedness and the classification of interest paid as CFC. This behavior may indicate that companies with an unfavorable financial situation tend to choose the classification that increases CFO. Thus, hypothesis $\mathrm{H}_{1}$ was not rejected.

The profitability variable was significant, which reveals that more profitable companies tend to choose the classification that increases CFO, this perhaps being a way of reinforcing their favorable situation, which is the direct opposite of $\mathrm{H}_{2}$, which considered that this tendency occurred in less profitable companies. $\mathrm{H}_{3}$ was rejected, since the negative $\mathrm{CFO}$ variable in accordance with the encouragement of CPC 03 was not significant in the results of the regressions. And the non-rejection of $\mathrm{H}_{4}$ reveals that the bigger the company, the greater the $\mathrm{CFO}$ presented, which may be related to internal incentives for favorable reports.

Despite the study being limited to some variables, these results present contributions, both to the consolidation of theories and to the set of empirical studies related to the topic and also to the improvement of accounting practice.

The contribution related to accounting choice theory and its empirical evidence involves the identification of evidence and indications of incentives that direct the choice of classifications in CFSs in the Brazilian setting. Despite there being empirical studies on this topic in Brazil (Silva et al., 2018; Souza et al., 2019), there are important differences, such as the extension of the period studied, the inclusion of control variables, and tests using two models. In addition, some of the results obtained here are consistent with the findings obtained in other international studies, especially those of Baik et al. (2016) and Gordon et al. (2017), which corroborate the conclusions that the level of indebtedness indeed appears to influence the accounting choices for classifying interest and dividends received or paid in CFSs. Thus, this study brings scientific implications to this field of knowledge, in that it confirms, with comprehensive data from the Brazilian market, what accounting choice theory predicts: choices are induced by economic incentives, such as indebtedness and profitability.

This study provides differentiated contributions by considering the "encouraged CFO" variable - if the company has negative CFO from following the encouragement of CPC 03 - not used by other research and by using the "sector" and "auditor" control variables in the Brazilian context.

For financial information users, knowing the choices and factors related to the classification of interest and dividends in CFSs helps in correctly analyzing these statements, and the other ones in combination. In the case of investors and creditors, who are aware of the use of this discretion and of the incentives that can affect CFO, they can make adjustments and use the adequate measure of CFO to estimate future cash flows, whether for the purposes of evaluating companies or financial analyses.

Understanding the discretion involved in CFSs, besides enabling an adequate comparison between companies, enables the alignment of the CFO measurement so that the subsequent accruals measurement is made correctly, when wanting to determine the level of earnings management. Another implication of this study refers to its relevance for standard setters, who can issue and/or revise accounting standards in response to the CFS choices that Brazilian companies have made and their impact.

In addition, this paper enables an understanding regarding the additional recommendations of the CPC in relation to IFRS, in an attempt to standardize the presentation of CFSs, as occurs in USGAAP. The results appear to indicate that this recommendation has not had an effect when there has been interest in a more favorable presentation of cash flows. Aware of this scenario, standard setters could evaluate up to what point it is beneficial to enable or not flexibility in CFS classifications. It is possible to perceive that the IASB has limited choices in other areas of accounting (such as, for example, the accounting of joint arrangements, financial instruments, and lease operations, among others). The evidence provided here may indicate the same path for CFSs.

Finally, when the use of the flexibility of CFS classifications is mentioned as supporting possible opportunistic behavior, this concerns the search for evidence of, for example, specific situations, such as the level of indebtedness, profitability, and size, which are factors identified in this study. Yet, it is not possible to state that, in all the cases with such evidence identified, the freedom of choice was used to generate the most convenient information. This impossibility occurs since there may be situations of companies that classify the items in their CFSs in the way that is considered the most correct from their viewpoint, independently of the economicfinancial context in which they find themselves, or there may be other incentives that influence that choice that have not been explored in this research, such as growth opportunities, companies under judicial reorganization, and the percentage of shares traded on the stock exchange in the period, to be analyzed in future research. In addition, analysts' decisions could be considered in future studies, in order to provide the perspective of these financial statement users in the analysis of CFSs. 


\section{REFERENCES}

Baik, B., Cho, H., Choi, W., \& Lee, K. (2016). Who classify interest payments as financing activities? An analysis of classification shifting in the Statement of Cash Flows at the adoption of IFRS. Journal of Accounting and Public Policy, 35(4), 331-351.

Burgstahler, D., \& Dichev, I. (1997). Earnings management to avoid earnings decreases and losses. Journal of Accounting and Economics, 24(1), 99-126.

Cabello, O. G., \& Pereira, C. A. (2015). Efeitos das práticas de tributação do lucro na effective tax rate (ETR): uma abordagem da teoria das escolhas contábeis. Advances in Scientific and Applied Accounting, 8(3), 356-373.

Comitê de Pronunciamentos Contábeis. (2010). CPC-03 (R2). Demonstração dos Fluxos de Caixa. Retrieved from http://www.cpc.org.br/CPC/Documentos-Emitidos/ Pronunciamentos/Pronunciamento? $\mathrm{Id}=34$.

Damodaran, A. (2006). Damodaran on valuation: Security analysis for investment and corporate finance (2a. ed.). Hoboken, NJ: Wiley.

Dichev, I. D., \& Skinner, D. J. (2002). Large-sample evidence on the debt covenant hypothesis. Journal of Accounting Research, 40(4), 1091-1123.

Estridge, J., \& Lougee, B. (2007). Measuring free cash flows for equity valuation: Pitfalls and possible solutions. Journal of Applied Corporate Finance, 19(2), 60-71.

Fields, T. D., Lys, T. Z., \& Vincent, L. (2001). Empirical research on accounting choice. Journal of Accounting and Economics, 31(1), 255-307.

Francis, J. (2001). Discussion of empirical research on accounting choice. Journal of Accounting and Economics, 31(1), 309-319.

Gordon, E. A., Henry, E., Jorgensen, B., \& Linthicum, C. L. (2017). Flexibility in cash flow reporting classification choices under IFRS. Review of Accounting Studies, 22(2), 839-872.

Gujarati, D. N. (2006). Econometria básica. Rio de Janeiro, RJ: Elsevier.

Holthausen, R. W. (1990). Accounting method choice: Opportunistic behavior, efficient contracting, and information perspectives. Journal of Accounting and Economics, 12(1), 207-218.

Holthausen, R. W., \& Leftwich, R. W. (1983). The economic consequences of accounting choice implications of costly contracting and monitoring. Journal of Accounting and Economics, 5(1), 77-117.

Lee, L. F. (2012). Incentives to inflate reported cash from operations using classification and timing. The Accounting Review, 87(1), 1-33.

Law n. $11,638 / 2007$, of December $28^{\text {th }}$ of 2007 . (2007, December $\left.28^{\text {th }}\right)$. Alters and revokes arrangements of Law n. 6,404, of December $15^{\text {th }}$ of 1976 , and of Law n. 6,358 , of December $7^{\text {th }}$ of 1976 , and extends to large-sized corporations arrangements related to the elaboration and disclosure of financial statements. Retrieved from http:// www.planalto.gov.br/ccivil_03/_ato2007-2010/2007/lei/ 111638.htm.

Law n. 6,404, of December $15^{\text {th }}$ of 1976 . (1976, December $\left.17^{\text {th }}\right)$. Describes Joint-Stock Companies. Retrieved from http://www. planalto.gov.br/ccivil_03/leis/16404consol.htm.
Law n. 9,249, of December $26^{\text {th }}$ of 1995 . (1995, December $27^{\text {th }}$ ). Alters the corporate act on Income Tax for companies, as well as on social contributions on net income, and makes other arrangements. Retrieved from http://www.normaslegais.com. br/legislacao/tributario/lei9249.htm.

Lorencini, F. D., \& Costa, F. M. (2012). Escolhas contábeis no Brasil: identificação das características das companhias que optaram pela manutenção versus baixa dos saldos do ativo diferido. Revista Contabilidade \& Finanças, 23(58), 52-64.

Maciel, F. F. S, Salotti, B. M., \& Imoniana, J. O. (2017). Escolhas contábeis na demonstração dos fluxos de caixa no contexto do mercado de capitais brasileiro. Revista Universo Contábil, 13(4), 194-211.

Martínez, J. A., Martínez, F. G., \& Diazaraque, J. M. M. (2011). Optional accounting criteria under IFRSs and corporate characteristics: Evidence from Spain. Revista de Contabilidad, 14(1), 59-85.

Missonier-Piera, F. (2004). Economic determinants of multiple accounting method choices in a Swiss context. Journal of International Financial Management \& Accounting, 15(2), 118-144.

Murcia, F. D.-R., Souza, M. M. de, Wuergues, A. F. E., \& Duarte, G. (2013). Realização ou estorno da reserva de reavaliação: fatores determinantes da escolha das companhias abertas no Brasil após o advento da Lei 11.638/07. Advances in Scientific and Applied Accounting, 6(1), 112-133.

Quagli, A., \& Avallone, F. (2010). Fair value or cost model? Drivers of choice for IAS 40 in the real estate industry. European Accounting Review, 19(3), 461-493.

Santos, A., \& Lustosa, P.R.B. (1999). Juros e dividendos pagos: onde classificá-los na demonstração dos fluxos de caixa? IOB Informações Objetivas, Temática Contábil e Balanços, 33(39), 1-7.

Santos, A., \& Lustosa, P.R.B. (2000). Recebimento de juros e dividendos na demonstração de fluxos de caixa: atividades operacionais ou de investimentos? IOB - Informações Objetivas, Temática Contábil e Balanços, 34(18), 1-6.

Scott, W. R. (2014). Financial accounting theory (7a. ed.). Toronto: Pearson Education.

Silva, D. M., Martins, V. A., \& Lima, F. G. (2018). Escolhas contábeis na demonstração dos fluxos de caixa em companhias listadas no novo mercado da B3. Revista Contemporânea de Contabilidade, 15(36), 143-165.

Souza, P. C., Pinto, A. F., Nunes, F. M., \& Lemes, S. (2019). Comparability of accounting choices in the statement of cash flow: Evidence from Brazil. Contaduría y Administración, 64(3), e106.

Sunder, S. (1997). Theory of accounting and control. Stamford, CT: South-Western Cengage Learning.

Watts, R. L. (1992). Accounting choice theory and market-based research in accounting. The British Accounting Review, 24(3), 235-267.

Watts, R. L., \& Zimmerman, J. L. (1986). Positive accounting theory. Upper Saddle River, NJ: Prentice-Hall Inc.

Watts, R. L., \& Zimmerman, J. L. (1990). Positive accounting theory: A ten year perspective. Accounting Review, 65(1), 131-156. 


\section{APPENDIX A}

Data with occurrences excluded from the sample

\begin{tabular}{|c|c|c|c|c|c|c|c|c|}
\hline Year & 2008 & 2009 & 2010 & 2011 & 2012 & 2013 & 2014 & Total \\
\hline \multicolumn{9}{|l|}{ Data inconsistencies } \\
\hline Companhia de Ferro Ligas da Bahia - FERBASA & & & & 1 & & 1 & & 2 \\
\hline Cr2 Empreendimentos Imobiliários S.A. & & 1 & & & & & & 1 \\
\hline Daleth Participações S.A. & & & & & 1 & & & 1 \\
\hline Desenvix Energias Renováveis S.A. & & & & & 1 & & & 1 \\
\hline Fibam Companhia Industrial & & & & & 1 & & & 1 \\
\hline Ideiasnet S.A. & & & & & & 1 & & 1 \\
\hline João Fortes Engenharia S.A. & & & & 1 & & & & 1 \\
\hline Log-In Logística Intermodal S.A. & & & & & & 1 & 1 & 2 \\
\hline Multiplan Empreendimentos Imobiliários S.A. & & 1 & & & & & & 1 \\
\hline PDG Realty S.A. Empreendimentos e Participações & 1 & & & & & & & 1 \\
\hline Total & 1 & 2 & & 2 & 3 & 3 & 1 & 12 \\
\hline \multicolumn{9}{|l|}{ CFS not presented, illegible, or incomplete } \\
\hline Centrais Elétricas Brasileiras S.A. - ELETROBRAS & & & & & 1 & & & 1 \\
\hline Companhia Energética de Pernambuco - CELPE & & & & & & 1 & & 1 \\
\hline Companhia Energética de São Paulo - CESP & & 1 & & & & & & 1 \\
\hline FG Holding International S.A. & & & & 1 & & & & 1 \\
\hline Log-In Logística Intermodal S.A. & & & & 1 & & & & 1 \\
\hline MAHLE Metal Leve S.A. & & & & 1 & & & & 1 \\
\hline Metalúrgica Duque S.A. & & & & & & 1 & & 1 \\
\hline Total & & 1 & & 3 & 1 & 2 & & 7 \\
\hline
\end{tabular}

CFS = Cash Flow Statement.

Source: Elaborated by the authors. 


\section{APPENDIX B - DATA FROM MODEL A}

Data on the variables of model $A$

\begin{tabular}{|c|c|c|c|c|c|}
\hline Variables & Period & Mean & $\mathbf{n}$ & Standard deviation & Median \\
\hline \multirow{8}{*}{$\begin{array}{l}\text { Dependent variable } \\
\text { Difference in reais } \\
\text { between the disclosed } \\
\text { CFO and encouraged } \\
\text { CFO divided by the value } \\
\text { of total assets }\end{array}$} & 2008 & 0.0081 & 64 & 0.05748 & 0.0000 \\
\hline & 2009 & 0.0085 & 67 & 0.04024 & 0.0000 \\
\hline & 2010 & 0.0014 & 70 & 0.05552 & 0.0100 \\
\hline & 2011 & 0.0140 & 81 & 0.03467 & 0.0200 \\
\hline & 2012 & 0.0102 & 89 & 0.02659 & 0.0100 \\
\hline & 2013 & 0.0084 & 108 & 0.03030 & 0.0100 \\
\hline & 2014 & -0.0029 & 106 & 0.12704 & 0.0100 \\
\hline & Total & 0.0065 & 585 & 0.06538 & 0.0100 \\
\hline \multirow{8}{*}{ Profitability } & 2008 & -3.7136 & 64 & 43.74277 & 2.7000 \\
\hline & 2009 & 4.9388 & 67 & 10.92714 & 4.0000 \\
\hline & 2010 & 4.7869 & 70 & 10.16828 & 4.3000 \\
\hline & 2011 & 4.1981 & 81 & 8.89029 & 4.4000 \\
\hline & 2012 & 0.3606 & 89 & 20.40381 & 2.8000 \\
\hline & 2013 & -3.7185 & 108 & 46.23418 & 2.8000 \\
\hline & 2014 & 72.4019 & 106 & 749.50581 & 3.2000 \\
\hline & Total & 13.8008 & 585 & 320.11134 & 3.3000 \\
\hline \multirow{8}{*}{ Debt } & 2008 & 69.8545 & 64 & 79.70254 & 58.3000 \\
\hline & 2009 & 61.8191 & 67 & 57.81431 & 53.4000 \\
\hline & 2010 & 64.7869 & 70 & 64.15549 & 55.4000 \\
\hline & 2011 & 60.6677 & 81 & 43.69228 & 57.1000 \\
\hline & 2012 & 62.5588 & 89 & 59.24189 & 57.0000 \\
\hline & 2013 & 64.8224 & 108 & 63.80535 & 54.3500 \\
\hline & 2014 & 63.6726 & 106 & 51.78391 & 57.3500 \\
\hline & Total & 63.8967 & 585 & 59.78372 & 56.2000 \\
\hline \multirow{8}{*}{ Size } & 2008 & 13.47 & 64 & 2.70 & 13.78 \\
\hline & 2009 & 14.11 & 67 & 1.98 & 14.29 \\
\hline & 2010 & 14.50 & 70 & 1.90 & 14.63 \\
\hline & 2011 & 14.67 & 81 & 1.82 & 14.71 \\
\hline & 2012 & 14.73 & 89 & 1.83 & 14.78 \\
\hline & 2013 & 14.82 & 108 & 1.66 & 14.99 \\
\hline & 2014 & 14.91 & 106 & 1.54 & 14.99 \\
\hline & Total & 14.53 & 585 & 1.93 & 14.71 \\
\hline
\end{tabular}

CFO = cash flow from operations.

Source: Elaborated by the authors.

Frequency of the encouraged cash flow from operations (CFO) variable (model A)

\begin{tabular}{lcccc}
\hline Encouraged CFO & $\begin{array}{c}\text { Positive } \\
\mathbf{n}(\boldsymbol{\%})\end{array}$ & $\begin{array}{c}\text { Negative } \\
\mathbf{n}(\mathbf{\%})\end{array}$ & $\begin{array}{c}\text { Blank } \\
\mathbf{n}(\mathbf{\%})\end{array}$ & $\begin{array}{c}\text { Total } \\
\mathbf{n}(\mathbf{\%})\end{array}$ \\
\hline 2008 & $47(27.5)$ & $17(9.9)$ & $107(62.6)$ & $171(100.0)$ \\
\hline 2009 & $55(32.2)$ & $12(7.0)$ & $104(60.8)$ & $171(100.0)$ \\
\hline 2010 & $54(31.6)$ & $16(9.4)$ & $101(59.1)$ & $171(100.0)$ \\
\hline 2011 & $59(34.5)$ & $22(12.9)$ & $80(52.6)$ & $171(100.0)$ \\
\hline 2012 & $74(43.3)$ & $15(8.8)$ & $63(36.8)$ & $171(100.0)$ \\
\hline 2013 & $85(49.7)$ & $23(13.5)$ & $65(38.0)$ & $171(100.0)$ \\
\hline Total & $87(50.9)$ & $19(11.1)$ & $612(51.1)$ & $171(100.0)$ \\
\hline
\end{tabular}

Source: Elaborated by the authors. 


\section{APPENDIX C - DATA FROM MODEL B}

Data on the variables of model $B$

\begin{tabular}{|c|c|c|c|c|c|}
\hline Variables & Period & Mean & $\mathbf{n}$ & Standard deviation & Median \\
\hline \multirow{8}{*}{ Profitability } & 2008 & -4.2227 & 94 & 44.82704 & 3.7500 \\
\hline & 2009 & 4.0619 & 117 & 14.63133 & 5.0000 \\
\hline & 2010 & 4.7793 & 162 & 11.29089 & 5.4500 \\
\hline & 2011 & 4.1024 & 176 & 9.35835 & 4.5000 \\
\hline & 2012 & 2.8272 & 193 & 9.20505 & 3.3000 \\
\hline & 2013 & -0.3005 & 199 & 34.65555 & 3.1000 \\
\hline & 2014 & 41.5440 & 200 & 544.52614 & 3.3000 \\
\hline & Total & 9.0878 & 1,141 & 228.97491 & 3.9000 \\
\hline \multirow{8}{*}{ Debt } & 2008 & 76.7962 & 94 & 75.71170 & 62.2500 \\
\hline & 2009 & 74.9369 & 117 & 76.77536 & 59.8000 \\
\hline & 2010 & 62.1357 & 162 & 46.13040 & 57.4400 \\
\hline & 2011 & 61.9335 & 176 & 44.07944 & 57.9900 \\
\hline & 2012 & 61.1641 & 193 & 30.35689 & 58.9000 \\
\hline & 2013 & 63.4889 & 199 & 36.79917 & 57.5000 \\
\hline & 2014 & 61.4030 & 200 & 24.88416 & 59.3000 \\
\hline & Total & 64.5682 & 1,141 & 46.83927 & 58.5000 \\
\hline \multirow{8}{*}{ Size } & 2008 & 14.09 & 94 & 1.92 & 14.38 \\
\hline & 2009 & 14.18 & 117 & 1.83 & 14.21 \\
\hline & 2010 & 14.57 & 162 & 1.70 & 14.59 \\
\hline & 2011 & 14.83 & 176 & 1.67 & 14.90 \\
\hline & 2012 & 14.95 & 193 & 1.56 & 15.04 \\
\hline & 2013 & 15.03 & 199 & 1.56 & 15.12 \\
\hline & 2014 & 15.06 & 200 & 1.55 & 15.21 \\
\hline & Total & 14.76 & 1,141 & 1.69 & 14.90 \\
\hline
\end{tabular}

Frequency of the interest paid and encouraged cash flow from operations variables (model B)

\begin{tabular}{|c|c|c|c|c|}
\hline Interest paid & $\begin{array}{c}0 \text { - CFO } \\
\text { n (\%) }\end{array}$ & $\begin{array}{c}1 \text { - CFF } \\
\text { n (\%) }\end{array}$ & $\begin{array}{l}\text { Bland } \\
\text { n (\%) }\end{array}$ & $\begin{array}{c}\text { Total } \\
\text { n (\%) }\end{array}$ \\
\hline 2008 & $53(22.6)$ & $41(17.5)$ & $140(59.8)$ & $234(100.0)$ \\
\hline 2009 & $70(29.9)$ & $47(20.1)$ & $117(50.0)$ & $234(100.0)$ \\
\hline 2010 & $101(43.2)$ & $61(26.1)$ & $72(30.8)$ & $234(100.0)$ \\
\hline 2011 & $112(47.9)$ & $64(27.4)$ & $58(24.8)$ & $234(100.0)$ \\
\hline 2012 & $119(50.9)$ & 74 (31.6) & $41(17.5)$ & $234(100.0)$ \\
\hline 2013 & $125(53.4)$ & 74 (31.6) & $35(15.0)$ & $234(100.0)$ \\
\hline 2014 & $123(52.6)$ & 77 (32.9) & $34(14.5)$ & $234(100.0)$ \\
\hline Total & $703(42.9)$ & $438(26.7)$ & $497(30.4)$ & 1,638 (100.0) \\
\hline Encouraged CFO & $\begin{array}{c}\text { Positive } \\
\text { n (\%) }\end{array}$ & $\begin{array}{c}\text { Negative } \\
\text { n (\%) }\end{array}$ & $\begin{array}{l}\text { Blank } \\
\text { n (\%) }\end{array}$ & $\begin{array}{l}\text { Total } \\
\text { n (\%) } \\
\end{array}$ \\
\hline 2008 & $72(30.8)$ & $22(9.4)$ & $140(59.8)$ & $234(100.0)$ \\
\hline 2009 & $100(42.7)$ & $17(7.3)$ & $117(50.0)$ & $234(100.0)$ \\
\hline 2010 & $131(56.0)$ & $31(13.2)$ & $72(30.8)$ & $234(100.0)$ \\
\hline 2011 & $141(60.3)$ & $35(15.0)$ & $58(24.8)$ & $234(100.0)$ \\
\hline 2012 & $158(67.5)$ & $35(15.0)$ & $41(17.5)$ & $234(100.0)$ \\
\hline 2013 & $158(67.5)$ & $41(17.5)$ & $35(15.0)$ & $234(100.0)$ \\
\hline 2014 & $166(70.9)$ & $34(14.5)$ & 34 (14.5) & $234(100.0)$ \\
\hline Total & $926(56.5)$ & $215(13.1)$ & $497(30.4)$ & $1,638(100.0)$ \\
\hline
\end{tabular}

CFF $=$ cash flow from financing activities; CFO = cash flow from operating activities.

Source: Elaborated by the authors. 